\title{
Quantification of drought tolerance in Ethiopian common bean varieties
}

\author{
Asrat Asfaw ${ }^{1^{*}}$, Matthew W. Blair ${ }^{2}$ \\ ${ }^{1}$ Hawassa Agricultural Research Centre, South Agricultural Research Institute, Hawassa, Ethiopia; \\ *Corresponding Author: asrat.asfaw@gmail.com \\ ${ }^{2}$ Department of Agricultural Sciences, Tennessee State University, Nashville, USA
}

Received October $26^{\text {th }}, 2013$; revised January $16^{\text {th }}, 2014$; accepted January $28^{\text {th }}, 2014$

Copyright (C) 2014 Asrat Asfaw, Matthew W. Blair. This is an open access article distributed under the Creative Commons Attribution License, which permits unrestricted use, distribution, and reproduction in any medium, provided the original work is properly cited. In accordance of the Creative Commons Attribution License all Copyrights (c) 2014 are reserved for SCIRP and the owner of the intellectual property Asrat Asfaw, Matthew W. Blair. All Copyright (C) 2014 are guarded by law and by SCIRP as a guardian.

\section{ABSTRACT}

Understanding the level of drought tolerance of the varieties available in each country is of paramount importance for breeding common bean for drought adaptation. The goal of this study was to evaluate 25 common bean genotypes of which 24 were released/recommended varieties for production by farmers and one was a drought tolerant check. The genotypes were planted at two sites in Ethiopia, Hawasssa and Amaro, using variable sowing dates, one that was early to avoid drought and one that was late to expose the crop to drought. The experiments were repeated over two years in Hawassa and one year in Amaro. This resulted in treatments with high and low total seasonal rainfall and six environments for analysis. The impact of drought stress on the trait expression of the varieties was not uniform across traits assessed and varieties tested. The effect of drought on photosynthate translocation and partitioning traits was much greater than on yield component traits in the varieties studied. This indicating less breeding efforts has been made in improving the varieties ability to mobilize photosynthate to the developing grain as compared to the yield component traits. Drought tolerant varieties like Hawassa Dume maintained better photosynthate translocation and partitioning than the drought sensitive varieties like Brown Speckled bean. Hawassa Dume also showed better yield stability and performed well under both drought stress and nonstress conditions. Our results indicate the relevance of high levels of photosynthate translocation and partitioning as an effective selection objective for improving drought tolerance in common bean. The information generated on the drought tolerance of the available varieties should help in the design of a breeding strategy that incorporates adaptation traits with commercial characteristics preferred by common bean farmers for varieties to be grown in diverse environments.

\section{KEYWORDS}

Drought Stress; Phaseolus vulgaris;

Photosynthate Translocation and Partitioning

Traits; Yield Stability

\section{INTRODUCTION}

Common bean (Phaseolus vulgaris L.) is the most important food legume in Ethiopia. While traditionally a food security crop throughout the country, its importance as a cash crop is gaining momentum in recent years through the sale of small white beans. These exportoriented beans have evolved into an important source of foreign currency for the country and income for smallholder farmers [1]. Common bean not only provides vital nutrients such as proteins, vitamins and minerals to the diets of the resource poor [2] but in Ethiopia is also important in providing fodder for feeding livestock and contributes to soil fertility improvement through atmospheric nitrogen fixation during the cropping season [3]. Thus as a legume, common beans add diversity to production systems on resource poor farmers' fields and contributes to the stability of farming systems in Ethiopia.

Common bean production in Ethiopia mainly occurs on smallholder farms prone to either intermittent or ter- 
minal drought risk [4]. In common bean, drought stress is more serious than other abiotic stresses making it a key challenge to the livelihood of vulnerable environments. Drought is estimated to cause significant harvest losses across sub-Saharan Africa, with an estimated yield reduction of 300,000 MT annually [5].

Many studies have shown that drought has a drastic effect on common bean crop performance. These include tissue specific plus whole plant effects [6-10]. Drought stress can cause flower abortion, pod drop, poor rates of photosynthesis and reduced seed filling [11]. Drought also affects overall biomass and seed yield, photosynthate translocation and partitioning, number of pods and seeds, seed weight, days to maturity and root length and mass [9,12-14]. In addition, drought reduces $P$ uptake as well as $\mathrm{N}$ concentration and fixation $[15,16]$.

In most parts of the world, drought episodes are becoming or are predicted to become more frequent in occurrence and often more intense in magnitude [10]. Complete or partial crop failure due to drought continues to be a common phenomenon $[17,18]$. Moreover, several places where drought is already a problem in Africa such as in Ethiopia and southern Africa will suffer from warmer and successively-drier weather linked with climate change over the next few decades [19]. Thus, drought stress is the most important limitation facing crops now and in the future.

Improving crop performance in harsh environments where drought is limiting remains one of the most important and challenging issues for breeders, farmers, researchers, development agents and policy makers. In some regions the challenge will be even more intimidating with an increasing scarcity of rainfall and water in the future. This will make improving adaptation to drought stress a major objective of many crop breeding efforts. Drought tolerance once packaged in the form of seed in a variety can easily be used by many farmers for battling against drought effects in common bean production.

Making significant genetic gain for adaptation to drought stress in breeding requires a better understanding of the level of drought tolerance in the current varieties used in each country. In this regard, our study will focus on the many genotypes of common bean developed for Ethiopia where regional preference differences demands a range in commercial seed classes. The levels of drought tolerance of these released/recommended genotypes for production by Ethiopian farmers have not been well documented. Indeed only a few studies have tested breeding lines for drought stress and farmers perception of their drought tolerance $[9,20,21]$. The overall objective of this study was to assess the level of drought tolerance in Ethiopian common bean released/recommended varieties for production by farmers.

\section{MATERIAL AND METHODS}

\subsection{Experimental Sites and Drought Trial}

Drought phenotyping experiments were conducted at two field sites in Ethiopia in the 2008 and 2009 cropping seasons: namely, Hawassa and Amaro research farms that belong to the South Agricultural Research Institute (SARI).

The Hawassa site is located at $7^{\circ} 03^{\prime} \mathrm{N}$ latitude, $38^{\circ} 30^{\prime} \mathrm{E}$ longitude at an elevation of $1700 \mathrm{~m}$ above sea level. The soil at this site is a well-drained sandy-loam (Flovisol, FAO classification) with $\mathrm{pH}$ 7.0. The yearly average maximum and minimum temperatures of the site are $26.9^{\circ} \mathrm{C}$ and $12.4^{\circ} \mathrm{C}$, respectively, and annual rainfall is $959 \mathrm{~mm}$ on average. Rainfall at this site is bimodal with total seasonal amount of $296 \mathrm{~mm}$ and $444 \mathrm{~mm}$ during the short "Belg" rainy season (March-May) and the long "Meher" rainy season (July-October), respectively.

The Amaro site is located at $5^{\circ} 50^{\prime} \mathrm{N}$ latitude, $37^{\circ} 55^{\prime} \mathrm{E}$ longitude at an elevation of $1426 \mathrm{~m}$ above sea level. The soil at this site is a well-drained silt-clay-loam (Eurtic nitosols, FAO classification) with $\mathrm{pH}$ 6.5. The yearly average maximum and minimum temperatures is $27.6^{\circ} \mathrm{C}$ and $15.2^{\circ} \mathrm{C}$, respectively, and annual rainfall is $927 \mathrm{~mm}$ (412 mm and $294 \mathrm{~mm}$ during the "Belg" and "Meher" growing seasons, respectively).

The trials were planted in the "Meher" (from JulyOctober) season at Hawassa across two years (2008 and 2009) and in the "Belg" (March-June) season at Amaro in 2009 using two different sowing dates in each season: one that was early to avoid drought and one that was late to expose the crop to terminal drought. The result was treatments with high and low total seasonal rainfall during the growing season. Total rainfall was recorded on a daily basis with a rain catchment system. Droughtstressed and nonstressed conditions were applied as separate experiments in each trial site which created six environments for analysis.

\subsection{Plant Material and Treatment Design}

Twenty four released/recommended varieties of common bean for Ethiopia of both large-seeded and smallseeded types as well as one small red-seeded drought tolerance check (SER108) obtained from the International Center for Tropical Agriculture (CIAT) were used for this study making a total of 25 genotypes in the experiment. The common bean material represented both Andean and Mesoamerican genepools with the list of the genotypes, genepool identity and their date of release presented in Table 1. An Andean drought-tolerant check genotype was not available at the time of the experiments but a recommended CIAT Andean line (AFR-702) was part of the list of recommended and released varieties 
Table 1. List of materials evaluated for the trial of Ethiopian varieties under drought and nonstress conditions in Hawassa and Amaro in southern Ethiopia over two years.

\begin{tabular}{|c|c|c|c|c|}
\hline Variety code & Name of varieties & Gene pool & Status & Year of release \\
\hline V1 & Denkenesh & Mesoamerican & Released variety & 2007 \\
\hline V2 & Dimitu & Mesoamerican & Released variety & 2003 \\
\hline V3 & Melkadima & Mesoamerican & Released variety & 2006 \\
\hline V 4 & Zebra & Mesoamerican & Released variety & 1999 \\
\hline V5 & Gofta & Mesoamerican & Released variety & 1997 \\
\hline V6 & Atndaba & Mesoamerican & Released variety & 1997 \\
\hline V7 & Awash Melka & Mesoamerican & Released variety & 1999 \\
\hline V8 & Naser & Mesoamerican & Released variety & 2003 \\
\hline V9 & Mex 142 & Mesoamerican & Released variety & 1973 \\
\hline V10 & Argene & Mesoamerican & Released variety & 2005 \\
\hline V11 & Chore & Mesoamerican & Released variety & 2006 \\
\hline V12 & Red Wolayta & Mesoamerican & Released variety & 1974 \\
\hline V13 & Ayenew & Mesoamerican & Released variety & 1997 \\
\hline V14 & Cranskope & Andean & Registered variety & 2007 \\
\hline V15 & Red Kidney & Andean & Registered variety & 2007 \\
\hline V16 & Awash-1 & Mesoamerican & Released variety & 1990 \\
\hline V17 & Omo-95 & Mesoamerican & Released variety & 2003 \\
\hline V18 & Ibado & Andean & Released variety & 2003 \\
\hline V19 & Goberasha & Andean & Released variety & 1999 \\
\hline V20 & Tabor & Mesoamerican & Released variety & 1999 \\
\hline V21 & Hawassa Dume & Mesoamerican & Released variety & 2008 \\
\hline V22 & SER-108 & Mesoamerican & Drought resistant check & $\#$ \\
\hline V23 & Brown Speckled & Andean & Unknown & NK \\
\hline V24 & AFR-702 & Andean & Recommended variety & 2004 \\
\hline V25 & RAB-585 & Mesoamerican & Recommended variety & 2004 \\
\hline
\end{tabular}

Note: NK= unknown, \# = drought tolerance check obtained from CIAT.

along with the CIAT Mesoamerican line (RAB-585). In all the experiments, a $5 \times 5$ triple lattice treatment design was used. The plot sizes were 4 rows of $2 \mathrm{~m}$ length by $0.4 \mathrm{~m}$ width. In all the experiments, DAP (diammonium phos- phate) fertilizer was applied at time of sowing at rate of $100 \mathrm{~kg} \cdot \mathrm{ha}^{-1}$ to raise a good crop. The experimental plots were hand weeded making the crop free of weed when- ever necessary.

\subsection{Plant Trait Measurements}

For quantifying the physiological differences in drought tolerance, a number of photosynthate translocation and partitioning (PTP) traits were measured through destructive sampling at mid-pod fill and at harvest maturity using the procedure specified by reference [9]. For the plant traits at mid-pod filling, a row length of $0.5 \mathrm{~m}(0.2$ $\mathrm{m}^{2}$ area) for each plot was selected and the plants were cut to the soil surface above the ground and put in a paper bag for processing in the laboratory. Plants were separated into leaves (without petioles), stems and the remaining (pods and reproductive structures) plant parts. The plant parts were put in separate paper bags and oven dried at $80^{\circ} \mathrm{C}$ for 2 days. After drying of the samples, dry weight of each sample was measured to determine total dry matter production and dry matter distribution in dif 
ferent plant parts (leaf biomass, stem biomass and pod biomass).

At harvest, plants within $0.5 \mathrm{~m}$ long row $\left(0.2 \mathrm{~m}^{2}\right.$ area $)$ were cut to the soil surface and oven dried at $80^{\circ} \mathrm{C}$ for 2 days. The oven dried samples were then separated into plant parts: stem, pod wall and seeds, and dry weight measurements were recorded. Physiological traits including, leaf stem ratio (LSR) at mid-pod fill, pod partitioning index (PPI), pod harvest index (PHI), stem biomass reduction (SBR) and harvest index (HI) at harvest maturity determined were as described in Reference [9]. These data were collected only at Hawassa in 2009 but not at Amaro 2008 and Hawassa 2008 due to labor shortage except for PHI which was measured in all experiments.

LSR was calculated as the ratio of dry matter distribution into leaf biomass and stem biomass at the mid-pod fill stage. PPI was determined as the ratio of dry weight of pods at harvest over dry weight of total biomass at the mid-pod fill stage multiplied by 100 . Similarly, PHI was calculated as the ratio of dry weight of seed over dry weight of pod at harvest multiplied by 100 . SBR was calculated as stem biomass at the mid-pod fill stage minus stem biomass dry weight at harvest over stem biomass dry weight at mid-pod fill multiplied by 100 . HI was determined as the ratio of seed dry weight at harvest over dry weight of total biomass at the mid-pod fill stage multiplied by 100 .

In addition, phenological traits like days to flowering (number of days from sowing to $50 \%$ plants at least one open flower in a plot) and days to maturity (number of days from sowing to at least $90 \%$ of plants reach physiological maturity in a plot) were recorded along with pods per plant, seeds per pod, grain yield (in $\mathrm{kg} \cdot \mathrm{ha}^{-1}$ ) and 100 seed weight in all experiments.

\subsection{Phenotypic Data Analysis}

Mixed model analyses of variance (ANOVAs) were carried out using the program Genstat v. 12.1 [22], first for single environments and then combined across environments to determine genotype $\times$ environment interaction $(\mathrm{G} \times \mathrm{E})$ following reference [23]. Both types of ANOVAs used a Residual Maximum Likelihood (REML) procedure. The models use were

$$
\mathrm{Y}_{\mathrm{iklm}}=\mu+\mathrm{g}_{\mathrm{i}}+\mathrm{m}_{\mathrm{k}}+\mathrm{r}_{\mathrm{l}}+\mathrm{b}_{\mathrm{m}}+\varepsilon_{\mathrm{iklm}}
$$

where $\mathrm{Y}$ is mean performance of a certain genotype, $\mu$ the overall mean, $g_{i}$ the effect of genotype $i, m_{k}$ the effect of genepool $\mathrm{k}, \mathrm{r}_{\mathrm{l}}$ the effect of replicate $\mathrm{l}, \mathrm{b}_{\mathrm{m}}$ the effect of block $\mathrm{m}$ and $\varepsilon_{\mathrm{iklm}}$ the residual associated with single plot for single environment analysis and

$$
\mathrm{Y}_{\mathrm{ijklm}}=\mu+\mathrm{g}_{\mathrm{i}}+\mathrm{e}_{\mathrm{j}}+\mathrm{ge}_{\mathrm{ij}}+\mathrm{m}_{\mathrm{k}}+\mathrm{r}_{\mathrm{l}}+\mathrm{b}(\mathrm{r})_{\mathrm{m}(\mathrm{l})}+\varepsilon_{\mathrm{ijklm}}
$$

where $\mathrm{Y}$ is mean performance of certain genotype, $\mu$ the overall mean, $g_{i}$ the effect of genotype $i, m_{k}$ the effect of genepool $k, e_{j}$ the effect of environment $j$, ge $e_{i j}$ the interaction between genotype $i$ and environment $j, r_{1}$ the effect of replicate $l, b(r)_{m(l)}$ the effect of block $m$ nested within replicate $l$ and $\varepsilon_{\mathrm{ijklm}}$ the residual associated with single plot for combined environment analysis.

In the single environment analysis, block effects were added to the model as a random effect when significant for a trait whereas replication was considered as a fixed effect. This was performed to remove the spatial variation within the trial field. Genotypes were considered as a fixed effect to get un-shrunken means (best linear unbiased estimates $=$ BLUEs).

For the combined environment $(\mathrm{G} \times \mathrm{E})$ analysis, blocks within replication, and environments were considered as random effects whereas replication and genotypes were modeled as fixed effects. For estimation of variance components in the combined environment or $\mathrm{G} \times \mathrm{E}$ model, genotypes were set as random. Variance components and broad-sense heritability $\left(h_{\text {BS }}^{2}\right)$ estimates were calculated for global (combined stress/nonstress environments) and set of drought stressed and nonstressed environments independently for making comparison. The broad sense heritability was estimated across e environments and $r$ replicates [24]

$$
h_{B S}^{2}=\frac{\sigma^{2} g}{\sigma^{2} g+\frac{\sigma^{2} g e}{e}+\frac{\sigma^{2} \varepsilon}{e r}}
$$

where $\sigma^{2} g, \sigma^{2} g e, \sigma^{2} \varepsilon$ are genetic, genotype $\times$ environment, and residual variance component respectively.

Phenotypic correlations between grain yield and other variables were assessed using Pearson's correlation coefficients as per a procedure implemented in the Genstat v. 12.1 programs. The significance of correlations was tested with t-tests based on the formula:

$$
t=r \sqrt{\frac{n-2}{1-r^{2}}}
$$

where the degrees of freedom was equal to $n-2$.

To quantify the severity of drought stress on grain yield, a drought intensity index (DII) for yield was calculated as DII $=1-G \bar{Y} p / G \bar{Y} i$, where $G \bar{Y} p$ and $G \bar{Y} i$ were the mean experimental yield values of all varieties grown under drought stress and nonstress, respectively [25]. Drought intensity index was also calculated for other traits measured in the trial adopting the formula for grain yield, one minus mean trait value under stress over nonstress for all the varieties and for the varieties in Andean and Mesoamerican genepool groups for comparison of drought tolerance level between varieties within genepool groups.

Other drought indices for grain yield, such as the stress tolerance index $\left(\mathrm{STI}=(\mathrm{GYi}) \times(\mathrm{GYp}) /(\mathrm{G} \overline{\mathrm{Y}} \mathrm{i})^{2}\right)$, 
geometric mean productivity $\left(\mathrm{GMP}=[(\mathrm{GYi}) \times(\mathrm{GYp})]^{0.5}\right)$ index, the mean productivity $(\mathrm{MP}=(\mathrm{GYi}+\mathrm{GPp}) / 2)$ index and the stress tolerance $(\mathrm{TOL}=(\mathrm{GYi}-\mathrm{GYp}))$ index were calculated as per procedures documented in reference [26,27]. In all cases GYi and GYp were the grain yields of varieties under nonstress and drought stress conditions, respectively. These indices were subjected to mixed model analysis to estimate variance components and means as model specified in Equation (2).

For assessing yield stability of the varieties, a genotype $\times$ environment $(G \times E)$ table was prepared using the BLUE means from the single environment analysis. Stability for grain yield and other traits (days to flowering, days to maturity, 100 seed weight, pod harvest index, pods per plant and seeds per pod) for which data were available for all the six test environments were computed using a cultivar superiority measure (Pi) of reference [28] as per procedures implement in Genstat v.12.1. Cultivar superiority (Pi) was estimated as

$$
\mathrm{Pi}=\sum_{\mathrm{j}=1}^{\theta}(\mathrm{Xij}-\mathrm{Mj})^{2} /(2 \mathrm{e})
$$

where e is the number of environment, Xij trait value of $\mathrm{i}^{\text {th }}$ variety grown in the $\mathrm{j}^{\text {th }}$ environment, $\mathrm{Mj}$ maximum trait value (response) of certain variety among all varieties in $\mathrm{j}^{\text {th }}$ environment. For days to flowering and days to maturity, $\mathrm{Pi}$ was estimated using $\mathrm{Mj}$ as minimum trait value of certain variety among all varieties in $j^{\text {th }}$ environment. In addition, a varietal evaluation was made based on both average grain yield and stability using the GGE biplot procedure of reference [29] in Genstat software.

\section{RESULTS}

\subsection{Level of Drought Stress and Effects on Mean Trait Values}

Weather conditions (rainfall amounts as well as maximum and minimum temperatures) during the crop growing period in each trial environment are presented in Figure 1. The average maximum and minimum temperatures for the Hawassa site 2008 were $24.7^{\circ} \mathrm{C}$ and $13.0^{\circ} \mathrm{C}$ in early planting and $25.5^{\circ} \mathrm{C}$ and $12.9^{\circ} \mathrm{C}$ in late planting; and $27.8^{\circ} \mathrm{C}$ and $12.2^{\circ} \mathrm{C}$ in nonstress (early planting) and $28.6^{\circ} \mathrm{C}$ and $11.5^{\circ} \mathrm{C}$ in terminal drought stress (late planting) in 2009. Rainfall events were sporadic (Figure 1(a), 1(b), 1(c), 1(d)).

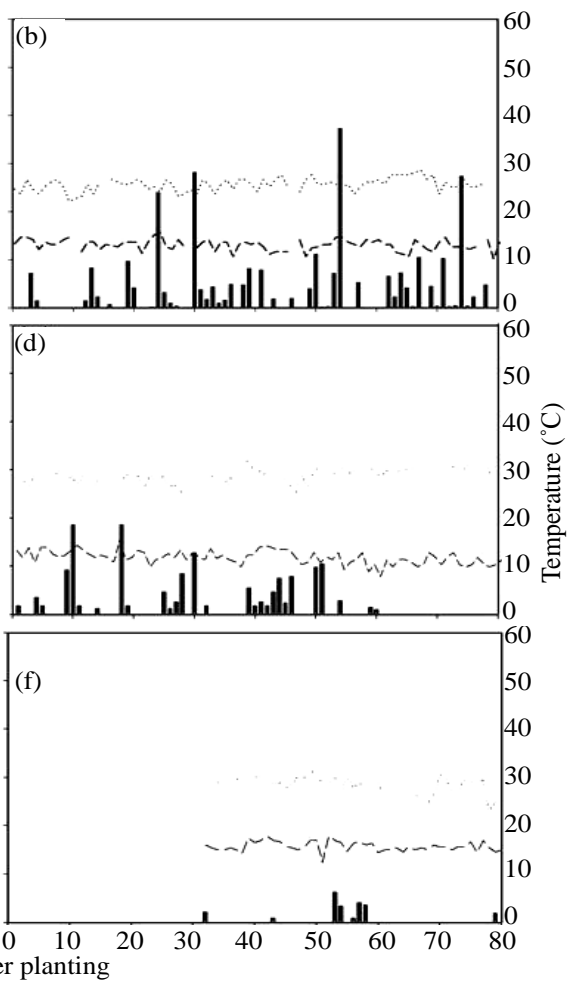

Figure 1. Rainfall distribution (bars), maximum and minimum temperatures (broken lines) during the crop growth period at different trial locations. (a) Hawassa early sowing 2008; (b) Hawassa late sowing 2008; (c) Hawassa early sowing 2009; (d) Hawassa late sowing 2009; (e) Amaro early sowing 2009; and (f) Amaro late sowing 2009, with the same x-axis in days after planting shown bottom of the subfigures for the two sites but with different $y$-axis to the right and left of the graphs. Subfigures (a), (d) and (f) were considered as drought stress (DS) environments and subfigures (b), (c) and (e) were taken as nonstress (NS) environments. 
The weather data of Amaro were not available for the full crop growing cycle. However, on the basis of the end of the season, the average maximum and minimum temperatures, respectively, were $20.2^{\circ} \mathrm{C}$ and $16.0^{\circ} \mathrm{C}$ in the nonstress trial (early planting) from 58 to 80 days after planting and $26.9^{\circ} \mathrm{C}$ and $15.4^{\circ} \mathrm{C}$ in the terminal droughtstress trial (late planting) from 32 to 80 days after planting. Again, rainfall was sporadic during the period of evaluation (Figures 1(e) and (f)).

The total rainfalls for the Hawassa early and late planting dates were $279 \mathrm{~mm}$ and $282 \mathrm{~mm}$ in 2008 cropping season and $235 \mathrm{~mm}$ and $149 \mathrm{~mm}$ in 2009 cropping season, respectively. The weather parameters during the crop growth period indicated that the crop suffered terminal drought stress in late planting trials at the Hawassa and Amaro sites in 2009 and intermittent drought stress mainly at flowering at the Hawassa site in the early but not the late planting in the 2008 cropping season. As a result, the Hawassa 2008 early planting was considered a drought-stressed environment and the Hawassa 2008 late planting trial which did not experience stress was considered a nonstress environment for the analysis in this paper.

Drought stress caused remarkable reduction in mean performance of the varieties for the traits studied except for leaf-stem dry weight ratio and stem biomass reduction (Table 2). Mean grain yield over the three environments was 55\% lower in the drought stress condition than in the nonstress condition based on the drought intensity index calculated from the mean yield of all varieties under stress versus nonstress environments. Average grain yields of all varieties including the drought tolerant check were 2950, 2514 and $1123 \mathrm{~kg} \cdot \mathrm{ha}^{-1}$ in the nonstress environments in Hawassa 2008, Hawassa 2009 and Amaro 2009, respectively. Meanwhile in the droughtstress environment of the same sites the yields were 2088, 508 and $375 \mathrm{~kg} \cdot \mathrm{ha}^{-1}$, respectively. As a result, the mean grain yield showed $29.2 \%, 79.8 \%$, and $66.6 \%$ reductions due to drought stress in the Hawassa 2008, Hawassa 2009, and Amaro 2009 trials, respectively. This showed that drought stress for grain yield was moderate in Hawassa 2008 but severe in Hawassa 2009 and Amaro 2009 cropping season trials.

Drought stress caused the varieties to flower and mature relatively faster. Drought stress also caused poor pod-partitioning and harvest index as shown by the other indices and traits evaluated at harvest: mean reductions due to drought stress were $70 \%$ for the pod-partitioning

Table 2. The effect of drought stress on mean trait value of common bean varieties (all 25 varieties irrespective of genepool grouping, 6 varieties in Andean and 19 varieties in Meso-American genepool groups) evaluated at drought stress and nonstress environments in Hawassa and Amaro sites in southern Ethiopia over two years. Mean trait values for photosynthate translocation and partitioning traits: leaf-stem ratio, pod portioning index, stem biomass reduction and harvest index were specific to Hawassa 2009 trial whereas for the rest of the traits measurements were made for Hawassa in 2008 and 2009 and for Amaro in 2009.

\begin{tabular}{|c|c|c|c|c|c|c|c|c|c|}
\hline \multirow{3}{*}{ Traits } & \multicolumn{6}{|c|}{ Mean values over environments ${ }^{*}$} & \multirow{2}{*}{\multicolumn{3}{|c|}{ Drought intensity index }} \\
\hline & \multicolumn{3}{|c|}{ NS } & \multicolumn{3}{|c|}{ DS } & & & \\
\hline & ALL & AND & MESO & ALL & AND & MESO & ALL & AND & MESO \\
\hline $\mathrm{DF}$ & 44.95 & 45.14 & 44.76 & 43.50 & 43.91 & 43.09 & 0.03 & 0.03 & 0.04 \\
\hline $\mathrm{DM}$ & 87.57 & 87.33 & 87.79 & 85.54 & 85.47 & 85.61 & 0.02 & 0.02 & 0.02 \\
\hline LSR & 1.31 & 1.28 & 1.34 & 1.30 & 1.00 & 1.60 & 0.01 & 0.22 & -0.19 \\
\hline PPI & 85.07 & 81.23 & 88.92 & 25.78 & 18.40 & 33.17 & 0.70 & 0.77 & 0.63 \\
\hline SBR & 46.08 & 46.89 & 45.27 & 54.71 & 53.52 & 55.90 & -0.19 & -0.14 & -0.23 \\
\hline PHI & 72.57 & 72.04 & 73.10 & 68.89 & 68.10 & 69.68 & 0.05 & 0.05 & 0.05 \\
\hline HI & 63.41 & 60.42 & 66.41 & 16.82 & 10.76 & 22.88 & 0.73 & 0.82 & 0.66 \\
\hline PPP & 13.05 & 12.52 & 13.58 & 10.17 & 10.87 & 9.47 & 0.22 & 0.13 & 0.30 \\
\hline SPP & 3.80 & 3.57 & 4.03 & 3.48 & 3.40 & 3.60 & 0.08 & 0.05 & 0.11 \\
\hline GYLD & 2195.38 & 1786.70 & 2324.43 & 990.48 & 884.82 & 1023.85 & 0.55 & 0.50 & 0.56 \\
\hline HSW & 28.50 & 30.97 & 26.03 & 25.39 & 25.39 & 24.73 & 0.11 & 0.18 & 0.05 \\
\hline
\end{tabular}

DF = Days to 50\% flowering; DM = Days to 90\% maturity; LSR = Leaf-stem ratio (dry weight); PPI = Pod partitioning index (\%); SBR = Stem biomass reduction (\%); PHI = Pod harvest index (\%); HI = Harvest index (\%); PPP = Pods per plant (number); SPP = Seeds per pod (number); GYLD = Grain yield kg. ha ${ }^{-1}$; $\mathrm{HSW}=100$ seed weight $(\mathrm{gm})$; ALL = All test genotypes; AND = Andean genepool groups; MESO = Meso-Ammerican genepool groups; NS = nonstress environments; DS = Drought stressed environments; Note: "Mean values over environment were based on $\mathrm{n}=3$ for days to $50 \%$ flowering, days to $90 \%$ maturity, pod harvest index, pods per plant, seeds per pod, grain yield $\mathrm{kg} \cdot \mathrm{ha}^{-1}$ and 100 seed weight whereas for the rest traits $\mathrm{n}=1$; $\mathrm{n}$ is number of environment. 
index, $5 \%$ for the pod harvest index, $75 \%$ for harvest index, $22 \%$ for the number of pods per plant, $8 \%$ for the number of seeds per pod and $11 \%$ for 100 seed weight. On the other hand, increased photosynthate mobilization from stem reserve was observed under drought stress environments compared to the nonstress environments. Under similar comparison, Andean varieties showed higher sensitivity to drought for expression of pod-partitioning index, harvest index and hundred seed weight whereas the Mesoamerican varieties were more sensitivity to drought in expression of pods per plant and seeds per pod (Table 2). In both genepool groups, the effect of drought on photosynthate mobilization from pod wall to the grain was small indicating varieties with better ability to translocating photosynthate from pod wall to grain under nonstress condition may repeat the same efficiency under drought stress environments too.

The responses of individual varieties even though not similar under the observed two drought patterns, the overall reduction in yielding potential and other trait performances were observed. Under the intermittent drought in Hawassa 2008, the varieties expressed better yielding potential and performance for other traits compared to the terminal drought effect in both Hawassa and Amaro sites in 2009 cropping season (Data not shown).

Such differences in varietal performance under the two drought patterns and also under nonstress environments were assessed with stability analysis section later in the paper rather than presenting the results to drought patterns differently.

\subsection{Variance Components, Heritability and Correlations of Grain Yield and Other Traits in the Environments}

Table 3 presents probability values for testing genotypic effect, the variance components and heritability of different traits assessed in the 25 common bean varieties and their correlations with grain yield under drought stressed and nonstressed environments. Considerable variation for the expression of phenotypic values was observed for the majority of the traits among the varieties. The varietal difference for drought stress and nonstress environments combined (global) analysis was highly significant $(\mathrm{p}<0.001)$ for expression of traits including days to $50 \%$ flowering, days to maturity, grain yield, hundred seed weight, pod harvest index, pods per plant, seeds per pod and mean performance. For parameters like leaf-stem ratio, stress tolerance index and geometric mean productivity, the varietal difference was significant at $5 \%$ probability. Nonsignificant differences were observed among varieties for expression of the traits; harvest index, pod partitioning index and stem biomass reduction within some individual sites. When independent
$\mathrm{G} \times \mathrm{E}$ analysis was conducted for the set of environments in drought stress and nonstress category, the varietal difference was significant for all traits measured under nonstress environments and except grain yield and leaf stem ratio under drought stress environments.

The $V_{G \times E}$ variance was greater than the genetic variance for the majority of traits measured and drought selection indices calculated in global as well as specific analysis for drought stress and nonstress environments independently. Higher $\mathrm{G} \times \mathrm{E}$ interaction was observed for grain yield $\left(\mathrm{kg} \cdot \mathrm{ha}^{-1}\right)$, days to maturity, leaf-stem ratio, pod partitioning index, harvest index, mean productivity, geometric mean productivity and stress tolerance indices in global analysis. On the other hand, the genetic variance $\left(V_{G}\right)$ was greater than $V_{G \times E}$ variance for days to $50 \%$ flowering, pods per plant, seeds per pod, 100 seed weight and stress tolerance index. For pods per plant under nonstress environments, the $\mathrm{V}_{\mathrm{G} \times \mathrm{E}}$ variance was higher compared to genetic variance. For photosynthate partitioning traits like stem biomass reduction and pod harvest index, the $\mathrm{V}_{\mathrm{G}}$ variance was almost equal to the $\mathrm{V}_{\mathrm{G} \times \mathrm{E}}$ variance.

The broad-sense heritability values in global analysis ranged substantially for all the traits measured and indices calculated, being especially low for pod partitioning index (0.18) but much higher for 100 seed weight (0.96) followed by days to $50 \%$ flowering $(0.94)$, stress tolerance index $(0.88)$, pods per plant $(0.80)$, and pod harvest index (0.75). The heritabilities were intermediate for grain yield (0.65), days to maturity (0.69), seeds per pod (0.61), and mean productivity (0.56). Relatively low heritabilities $(0.24-0.44)$ were observed for leaf-stem ratio, stem biomass reduction, harvest index, geometric mean productivity and stress tolerance. The heritabilities were observed to be generally lower in drought stress environments compared to the nonstress environments for majority of the traits except pods per plant, pod partitioning index and harvest index.

The phenotypic Pearson's correlation values between traits and grain yield are shown in the last columns of Table 3 for both drought and nonstress environments. Positive and significant associations were observed between grain yield and days to $50 \%$ flowering, days to $90 \%$ maturity, seeds per pod, pod harvest index, stress tolerance index, mean productivity and geometric mean productivity over drought stress and nonstress environments.

Under drought-stress environments, the correlations with grain yield were positive and significant for yield component traits, pods per plant and for the photosynthate partitioning trait for harvest index. The pod-partitioning index had positive but nonsignificant correlation with grain yield under both drought stress and nonstress environments while the correlations with grain yield were negative and nonsignificant for leaf-stem ratio and 
Table 3. Probability values for testing genotypic effect, estimates of variance components [genetic $\left(\sigma_{g}^{2}\right)$, genotype $\times$ environment interaction ( $\sigma_{g e}^{2}$ ) and phenotypic $\left(\sigma_{p}^{2}\right)$ ], broad-sense heritability ( $h_{\mathrm{BS}}^{2}$ ) global (all test environments stress and nonstress combined), drought stress and nonstress environments separate, and phenotypic correlations of traits and drought indices with grain yield of common bean varieties evaluated at drought stress and nonstress environments in Hawassa and Amaro in southern Ethiopia over two years.

\begin{tabular}{|c|c|c|c|c|c|c|c|c|c|c|c|c|c|c|c|c|c|}
\hline \multirow{3}{*}{ Traits } & \multicolumn{12}{|c|}{ Variance component } & \multirow{2}{*}{\multicolumn{3}{|c|}{$\begin{array}{l}\text { Heritability } \\
\text { broad } \\
\text { sense }\left(h^{2}{ }_{B S}\right)\end{array}$}} & \multirow{2}{*}{\multicolumn{2}{|c|}{$\begin{array}{c}\text { Correlation } \\
\text { with grain } \\
\text { yield } \mathrm{kg} \cdot \mathrm{ha}^{-1}\end{array}$}} \\
\hline & \multicolumn{4}{|c|}{ Global } & \multicolumn{4}{|c|}{ DS } & \multicolumn{4}{|c|}{ NS } & & & & & \\
\hline & p-values & $\sigma_{g}^{2}$ & $\sigma_{g e}^{2}$ & $\sigma_{p}^{2}$ & P-values & $\sigma_{g}^{2}$ & $\sigma_{g e}^{2}$ & $\sigma_{p}^{2}$ & P-values & $\sigma_{g}^{2}$ & $\sigma_{g e}^{2}$ & $\sigma_{p}^{2}$ & Global & DS & NS & DS & NS \\
\hline GYLD & 0.001 & 53676 & 136009 & 82931 & 0.423 & 1889 & 102288 & 36812 & 0.005 & 103268 & 168473 & 161615 & 0.65 & 0.05 & 0.64 & 1 & 1 \\
\hline \multicolumn{18}{|c|}{ Phenology } \\
\hline $\mathrm{DF}$ & 0.001 & 7.67 & 2.129 & 8.13 & 0.001 & 5.79 & 3.78 & 7.08 & 0.001 & 8.855 & 0.92 & 9.19 & 0.94 & 0.82 & 0.96 & $0.19^{* *}$ & $0.38^{* * * *}$ \\
\hline DM & 0.001 & 2.32 & 4.501 & 3.34 & 0.001 & 1.59 & 4.91 & 3.30 & 0.037 & 1.789 & 5.08 & 3.54 & 0.69 & 0.48 & 0.51 & $0.81^{* * *}$ & $0.72^{* * *}$ \\
\hline \multicolumn{18}{|c|}{ Yield components } \\
\hline PPP & 0.001 & 5.57 & 4.53 & 7.01 & 0.001 & 4.10 & 2.66 & 5.11 & 0.002 & 6.54 & 7.24 & 9.13 & 0.80 & 0.80 & 0.72 & $0.45^{* * *}$ & 0.05 \\
\hline SPP & 0.001 & 0.39 & 0.17 & 0.63 & 0.005 & 0.30 & 0.18 & 0.38 & 0.001 & 0.53 & 0.13 & 0.58 & 0.61 & 0.80 & 0.91 & $0.53^{* * * *}$ & $0.34^{* * * *}$ \\
\hline HSW & 0.001 & 50.77 & 4.99 & 52.62 & 0.001 & 32.19 & 4.13 & 33.82 & 0.001 & 72.89 & 2.62 & 73.99 & 0.96 & 0.95 & 0.99 & 0.07 & -0.23 \\
\hline \multicolumn{18}{|c|}{ Physiological traits } \\
\hline LSR & 0.05 & 0.03 & 0.07 & 0.09 & 0.402 & 0.19 & & 0.96 & 0.001 & 0.0392 & & 0.05 & 0.34 & 0.20 & 0.82 & -0.04 & -0.07 \\
\hline SBR & 0.127 & 34.8 & 35.1 & 88.43 & 0.021 & 83.70 & & 99.3 & 0.003 & 91.8 & & 104.5 & 0.39 & 0.84 & 0.88 & -0.20 & -0.11 \\
\hline PPI & 0.320 & 9.1 & 50.5 & 51.18 & 0.001 & 73.73 & & 79.97 & 0.009 & 39.5 & & 49.13 & 0.18 & 0.92 & 0.80 & 0.21 & 0.12 \\
\hline PHI & 0.001 & 6.48 & 6.84 & 8.62 & 0.055 & 9.88 & 8.71 & 13.10 & 0.003 & 4.93 & 2.76 & 6.01 & 0.75 & 0.75 & 0.82 & $0.53^{* * *}$ & $0.50^{* * * *}$ \\
\hline HI & 0.251 & 6.97 & 22.83 & 28.56 & 0.001 & 46.69 & & 51.00 & 0.04 & 13.85 & & 20.55 & 0.24 & 0.92 & 0.67 & $0.23^{*}$ & 0.17 \\
\hline \multicolumn{18}{|c|}{ Drought indices } \\
\hline STI & 0.049 & 0.09 & 0.03 & 0.11 & & & & & & & & & 0.88 & & & $0.84^{* * *}$ & $0.60^{* * *}$ \\
\hline MP & 0.009 & 46106 & 91371 & 8295 & & & & & & & & & 0.56 & & & $0.87^{* * * *}$ & $0.91^{* * * *}$ \\
\hline GM & 0.045 & 29972 & 99758 & 6840 & & & & & & & & & 0.44 & & & $0.95^{* * * *}$ & $0.80^{* * * *}$ \\
\hline TOL & 0.128 & 38338 & 179160 & 12274 & & & & & & & & & 0.31 & & & -0.32 & $0.58^{* * *}$ \\
\hline
\end{tabular}

Note: For abbreviations of traits refer Table 2 and abbreviations for drought indices are the following: STI = Stress tolerance index, GMP = Geometric mean productivity, MP = Mean productivity, TOL = Stress tolerance, correlations between yield and physiological parameter allude to where the parameters measured at Hawassa in 2009; ${ }^{*},{ }^{* * *},{ }^{* * *}$ indicates significance at $\mathrm{p}<0.05, \mathrm{p}<0.001$ and $\mathrm{p}<0.0001$ level, respectively.

stem biomass reduction at both Hawassa and Amaro sites. The relationship between grain yield and 100 seed weight was positive and nonsignificant under drought stress and negative and nonsignificant under nonstress environments. Grain yield was correlated with stress tolerance index in drought-stress environments.

\subsection{Varietal Performances under Drought Stress and Drought Selection Indices}

Mean grain yield over environments and drought selection indices are presented in Table 4. Under drought stress conditions, the grain yield of 25 varieties ranged from 441 to $1384 \mathrm{~kg} \cdot \mathrm{ha}^{-1}$. Among the varieties eva- luated, Dimitu, Red Wolayta, Omo-95 and Hawassa Dume from the Mesoamerican genepool, and Ibado and AFR-702 from the Andean genepool expressed better adaptation to the drought stress conditions.

Among these better adapted drought stress tolerant varieties, Hawassa Dume was also responsive to well-watered condition. Brown Speckled and Cranskope were the most poorly adapted varieties both under nonstress and drought stressed conditions. Based on different drought selection indices, varieties like Hawassa Dume and Red Wolayta with high STI, MP and GMP values were better yielding under both regimes.

Conversely, the variety ranking with stress tolerance 
Table 4. Mean grain yield and drought selection indices over six environments for 25 common bean varieties grown in nonstress and drought stress environments in Hawassa and Amaro in southern Ethiopia over two years.

\begin{tabular}{|c|c|c|c|c|c|c|}
\hline \multirow{2}{*}{ Varieties } & \multicolumn{2}{|c|}{ Mean grain yield $\mathrm{kg} \cdot \mathrm{ha}^{-1}$ over environments $(\mathrm{n}=3)$} & \multicolumn{4}{|c|}{ Drought indices } \\
\hline & Non-stress & Drought stress & STI & GM & MP & TOL \\
\hline Denkenesh & 2476.0 & 1050.5 & 0.57 & 1520 & 1765 & 1408 \\
\hline Dimitu & 2012.4 & 1384.4 & 0.51 & 1553 & 1675 & 623 \\
\hline Melkadima & 2202.0 & 1006.2 & 0.45 & 1409 & 1611 & 1224 \\
\hline Zebra & 2791.4 & 1083.4 & 0.49 & 1590 & 1922 & 1723 \\
\hline Gofta & 2024.8 & 787.9 & 0.29 & 1152 & 1382 & 1284 \\
\hline Atndaba & 2360.0 & 1030.8 & 0.38 & 1405 & 1665 & 1365 \\
\hline Awash Melka & 1872.8 & 970.7 & 0.30 & 1207 & 1413 & 876 \\
\hline Naser & 2671.4 & 949.2 & 0.51 & 1560 & 1806 & 1709 \\
\hline Mex 142 & 1761.3 & 793.6 & 0.27 & 1101 & 1282 & 964 \\
\hline Argene & 1878.6 & 847.0 & 0.36 & 1228 & 1374 & 1027 \\
\hline Chore & 2218.7 & 952.8 & 0.42 & 1401 & 1592 & 1270 \\
\hline Red Wolayta & 2429.7 & 1335.8 & 0.71 & 1771 & 1920 & 1091 \\
\hline Ayenew & 2064.6 & 1045.3 & 0.39 & 1417 & 1565 & 1011 \\
\hline Cranskope & 1412.7 & 558.5 & 0.13 & 832 & 991 & 833 \\
\hline Red Kidney & 1598.1 & 1060.5 & 0.27 & 1156 & 1312 & 578 \\
\hline Awash-1 & 2602.9 & 1085.2 & 0.54 & 1583 & 1839 & 1571 \\
\hline Omo-95 & 2426.4 & 1269.7 & 0.53 & 1627 & 1842 & 1157 \\
\hline Ibado & 2192.4 & 1169.1 & 0.45 & 1516 & 1691 & 1032 \\
\hline Goberasha & 1882.4 & 974.0 & 0.32 & 1264 & 1446 & 926 \\
\hline Tabor & 2080.9 & 826.4 & 0.34 & 1286 & 1479 & 1272 \\
\hline Hawassa Dume & 3322.2 & 1186.1 & 0.77 & 1948 & 2253 & 2082 \\
\hline SER-108 & 2438.1 & 929.2 & 0.45 & 1451 & 1683 & 1454 \\
\hline Brown Speckled & 1480.2 & 441.2 & 0.19 & 797 & 962 & 996 \\
\hline AFR-702 & 2154.4 & 1105.6 & 0.50 & 1488 & 1634 & 1071 \\
\hline RAB-585 & 2530.0 & 918.9 & 0.45 & 1478 & 1721 & 1580 \\
\hline ASED & 392.3 & 125.1 & $0.158^{*}$ & $279.2^{*}$ & $274.5^{* *}$ & (415.1) \\
\hline
\end{tabular}

Note: ASED = Average Standard Error of Difference, ${ }^{*}$ and ${ }^{* *}$ indicates probability level $5 \%$ and $1 \%$ respectively; Abbreviations for drought indices are the following: STI = Stress tolerance index, GMP = Geometric mean productivity, MP = Mean productivity, TOL = Stress tolerance.

index (TOL) was in reverse order from that of the other indices considered. Accordingly, Hawassa Dume which ranked first according to the STI, MP and GMP values ranked last with TOL values. Red Kidney was identified as the best in the degree of tolerance to drought with TOL values but it was not a high yielding variety under well-watered conditions.

Figures 2 and 3 present the relationship between grain yield and photosynthate translocation and partitioning (PTP) traits under drought stress and nonstress condi- tions. The relationship between grain yield and pod harvest index showed that the variety Hawassa Dume was outstanding in mobilizing photosynthates to seed development both under drought stress and nonstress condition. Meanwhile, Red Wolayta and Brown Specked showed poor ability to partition photosynthetically assimilated carbon to seed as reflected by lower values of pod harvest index under both nonstress and drought stress conditions.

For other traits, Red Wolayta, Omo-95 and Ibado were 

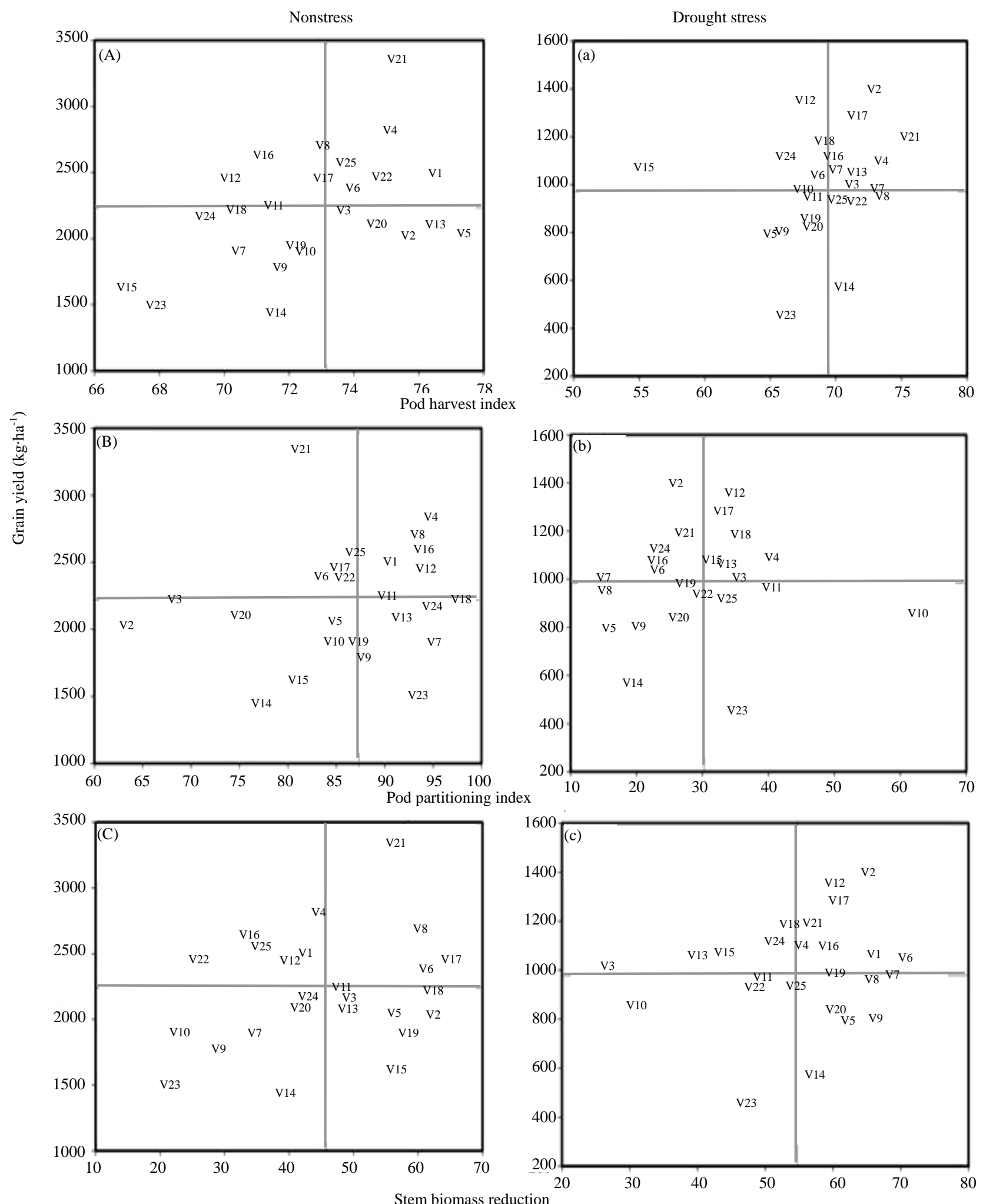

Figure 2. Relationship between grain yield and photosynthate translocation and partitioning (PTP) traits: pod harvest index (A), (a), pod partitioning index (B), (b) and stem biomass reduction (C), (c) of the 25 common bean varieties evaluated in southern Ethiopia under drought stress and nonstress condition. Capitalized letters indicate nonstress conditions and non-capitalized letters indicate corresponding drought stress conditions. Pod partitioning index and stem biomass reduction were measured in Hawassa 2009 while pod harvest index was measured in all test environments (Hawassa 2008 and 2009 and in Amaro 2009). 


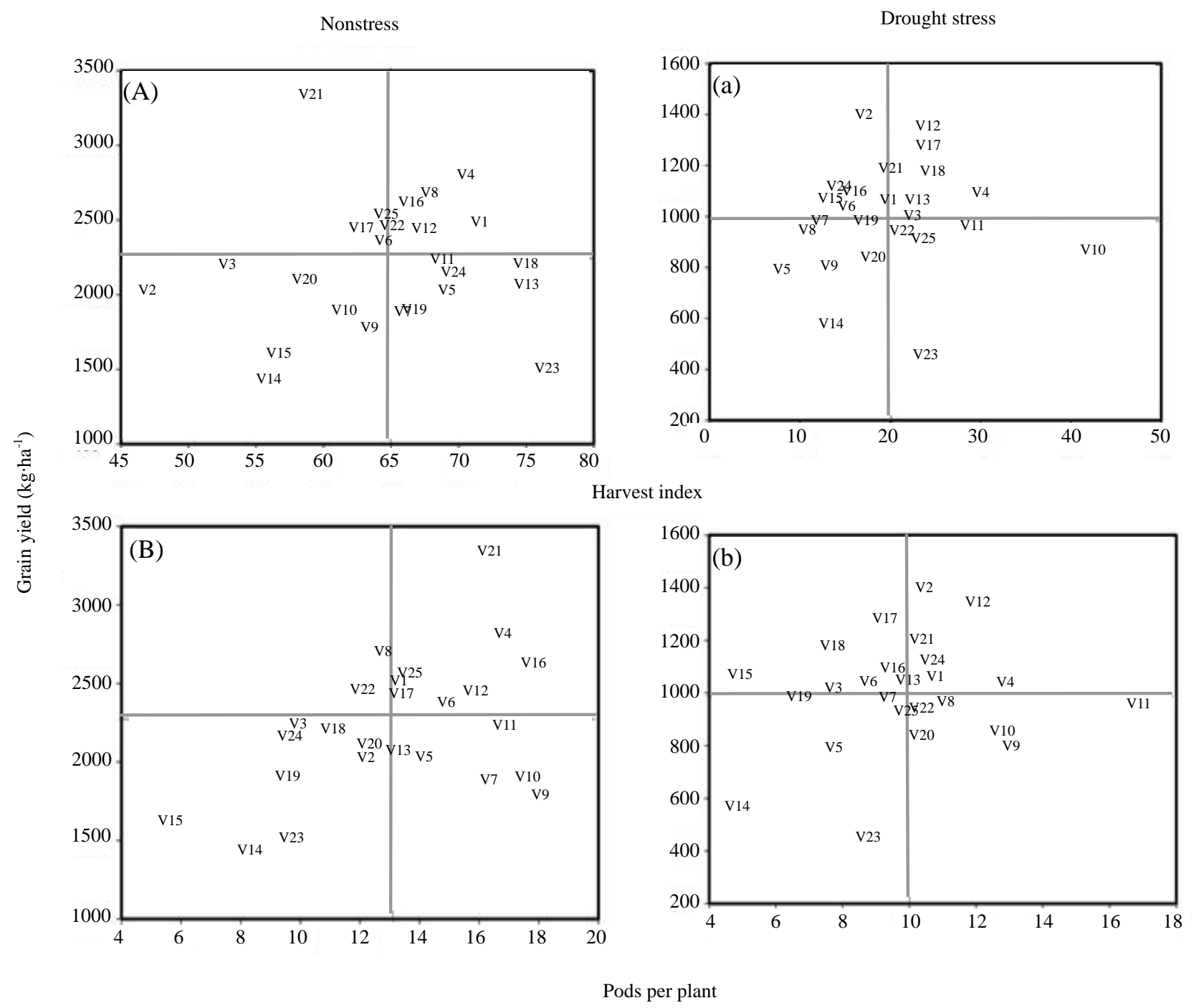

Figure 3. Relationship between grain yield with harvest index (A), (a) and pods per plant (B), (b) of 25 common bean varieties evaluated in southern Ethiopia under drought stress and nonstress conditions. Capitalized letters indicate nonstress conditions and non-capitalized letters indicate corresponding drought stress conditions, Harvest index was measured in Hawassa 2009 while pods per plant were measured in all test environments (Hawassa 2008 and 2009 and in Amaro 2009).

good in maintaining better grain yield with better pod partitioning index under both regimes whereas Argene showed outstanding performance for mobilization of photosynthates to pods under drought stress but poor ability to partition assimilated carbon onto the seeds in the development of higher yields.

Varieties like Omo-95, Dimitu and Hawassa Dume expressed better potential in mobilizing greater proportion of photosyntates from stem to pod and seed formation both under drought stress and nonstress condition as this was revealed by above average grain yield and stem biomass reduction values (Figures 2(C), (c)).

The relationship between grain yield and pods per plant showed that varieties Mex 142, Argene and Chore were outstanding in forming higher number of pods per plant under both drought stress and nonstress but were not among the highest yielding varieties under both regimes (Figures 3(B), (b)).

\subsection{Stability for Grain Yield and Other Traits}

Table 5 presents mean grain yield over test environments and estimates of stability of the varieties for yield and other traits using cultivar superiority measure. Evaluating varieties based on mean grain yield and stability parameter identified Hawassa Dume as the best variety that combined high mean yield with best estimate for cultivar superiority measure. The drought adapted varieties Dimitu, Red Wolayta and Omo-95 from the Mesoamerican genepool and Ibado and AFR 702 from the Andean genepool were good in producing above-average 
Table 5. Stability for grain yield, hundred seed weight, pod harvest index, pods per plant, seeds per plant, days to flowering and days to maturity of 25 common bean varieties evaluated under nonstress and drought stress environments in Hawassa and Amaro in southern Ethiopia over two years.

\begin{tabular}{|c|c|c|c|c|c|c|c|c|}
\hline \multirow{2}{*}{ Varieties } & \multirow{2}{*}{ Mean grain yield $\mathrm{kg} \cdot \mathrm{ha}^{-1}$} & \multicolumn{7}{|c|}{ Cultivar superiority measure $(\mathrm{Pi})$} \\
\hline & & Grain yield & HSW & PHI & PPP & SPP & $\mathrm{DF}$ & $\mathrm{DM}$ \\
\hline Denkenesh & 1745 & 373,549 & 44 & 5 & 11 & 1 & 13 & 11 \\
\hline Dimitu & 1677 & 500,738 & 49 & 3 & 15 & 0 & 14 & 8 \\
\hline Melkadima & 1620 & 651,707 & 3 & 5 & 20 & 1 & 1 & 2 \\
\hline Zebra & 1930 & 217,144 & 25 & 4 & 7 & 1 & 5 & 9 \\
\hline Gofta & 1430 & 781,755 & 20 & 10 & 11 & 1 & 2 & 5 \\
\hline Atndaba & 1705 & 429,717 & 27 & 7 & 11 & 1 & 5 & 4 \\
\hline Awash Melka & 1398 & 778,238 & 69 & 9 & 9 & 0 & 13 & 7 \\
\hline Naser & 1789 & 322,901 & 48 & 5 & 11 & 0 & 3 & 8 \\
\hline Mex 142 & 1261 & 939,566 & 62 & 13 & 5 & 0 & 8 & 8 \\
\hline Argene & 1351 & 848,860 & 75 & 8 & 5 & 0 & 8 & 9 \\
\hline Chore & 1595 & 517,133 & 64 & 9 & 4 & 0 & 15 & 14 \\
\hline Red Wolayta & 1912 & 285,915 & 48 & 11 & 7 & 0 & 11 & 9 \\
\hline Ayenew & 1567 & 606,345 & 8 & 4 & 12 & 1 & 1 & 4 \\
\hline Cranskope & 995 & $1,496,521$ & 15 & 7 & 23 & 1 & 6 & 5 \\
\hline Red Kidney & 1372 & $1,141,610$ & 1 & 35 & 30 & 1 & 0 & 1 \\
\hline Awash-1 & 1889 & 230,671 & 64 & 9 & 7 & 0 & 4 & 8 \\
\hline Omo-95 & 1853 & 303,869 & 55 & 5 & 13 & 0 & 9 & 7 \\
\hline Ibado & 1692 & 446,930 & 4 & 8 & 18 & 1 & 2 & 4 \\
\hline Goberasha & 1444 & 766,991 & 12 & 7 & 21 & 1 & 2 & 6 \\
\hline Tabor & 1474 & 682,599 & 49 & 6 & 13 & 0 & 13 & 10 \\
\hline Hawassa Dume & 2217 & 75,337 & 34 & 2 & 11 & 0 & 4 & 7 \\
\hline SER-108 & 1642 & 533,097 & 31 & 4 & 12 & 1 & 2 & 3 \\
\hline Brown Speckled & 926 & $1,775,030$ & 24 & 14 & 18 & 1 & 4 & 2 \\
\hline AFR-702 & 1647 & 520,945 & 15 & 10 & 17 & 1 & 3 & 7 \\
\hline RAB-585 & 1693 & 367,199 & 40 & 5 & 13 & 0 & 2 & 4 \\
\hline
\end{tabular}

Abbreviations for traits are the following: HSW = 100 seed weight $(\mathrm{gm}), \mathrm{PHI}=$ Pod harvest index $(\%)$, PPP = Pods per plant, SPP = Seeds per pod, DF = Days to $50 \%$ flowering, DM $=$ Days to $90 \%$ maturity.

grain yield but were not identified as stable by stability parameter values.

Andean varieties Red Kidney and Ibado, and Mesoamerican varieties Melkadima and Ayenew showed stability for expression of the trait 100 seed weight. Majority of the Mesoamerican varieties such as Dimitu, Zebra, Denkenesh, Nasir, Omo-95, Hawassa Dume, SER-108 and RAB-585 had best cultivar superiority estimates for pod harvest index indicating their stable performance across drought stress and nonstress environments in translocating photosynthetically assimilated carbon from pod wall to the grain. None of the Andean varieties showed the same level stability for pod harvest index as the Mesoamerican varieties but Ibado, Goberasha and Cranskope had relatively lower cultivar superiority estimates for the trait. Varieties Argene, Mex 54 and Chore from Mesoamerican group showed stable performance for pods per plant whereas none from the Andean varieties. Majority of the Mesoamerican varieties such as Dimitu, Awasha Melka, Nasir, Mex142, Argene, Red Wo- 
layta, Awash1, Omo-95, Tabor, Hawassa Dume and RAB-585 had best cultivar superiority estimates for expression the trait seeds per pod whereas none of the Andean varieties had best estimate for the trait. Mesoamerican varieties such as Melkadima, Gofta, Atendaba, Ayenew, SER-108 and RAB-585 and Andean varieties such as Red Kidney, Ibado and Brown Speckled recorded best estimates of cultivar superiority for both days to flowering and maturity.

The GGE biplot ranking of varieties based on both mean grain yield and stability performance also identified Hawassa Dume (V21) as superior (Figure 4) being located at the center of the concentric circles where an ideal cultivar should be. The terminal drought stress environment at Amaro in 2009 season (AMDS09) lacks correlation with the rest environments for varietal performance in grain yield. In this environment where the plants suffered a lot from terminal drought, Red Wolayta performed better. The Andean varieties Cranskope (V14) and Brown Speckled (V23) and Mesoamerican variety Mex 142 (V9) were inferior in both mean grain yield and stability performance being located at far end of the concentric circles for the ideal cultivar in the figure.

\section{DISCUSSION}

\subsection{Choice of Test Environments in the Field Study}

Assessing the level of drought tolerance of materials
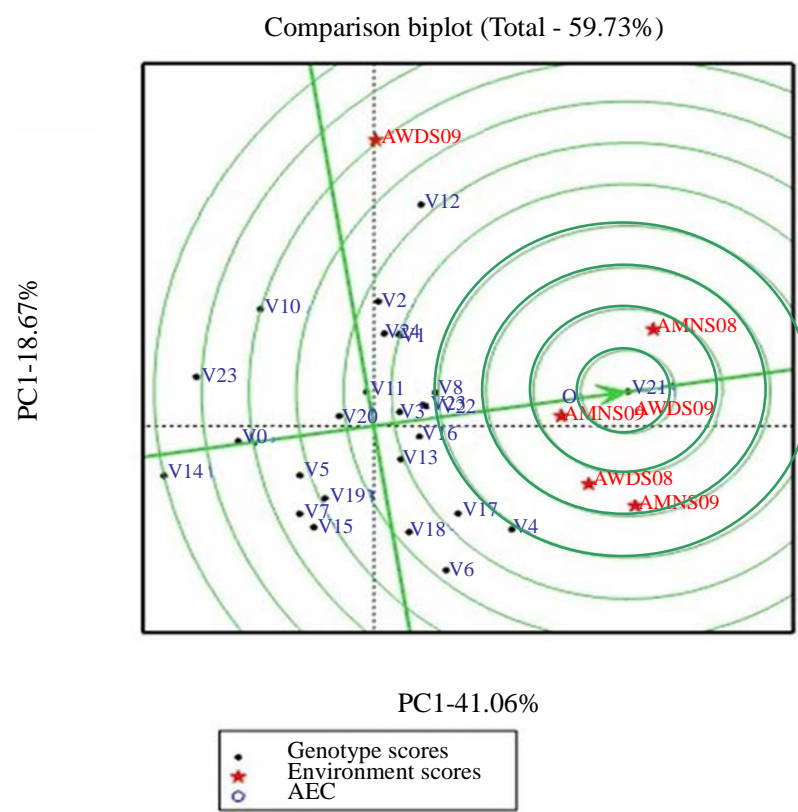

Figure 4. GGE biplot ranking of varieties based on both average grain yield and stability for grain yield across 6 environments under drought and nonstress conditions at the site in Hawassa over two years and Amaro in one year in southern Ethiopia during 2008 and 2009. in a breeding program requires the comparison of performance in nonstress and stress environment experiments. This should be accomplished by a careful choice of test environments. This study assessed the level of drought tolerance in Ethiopian common bean varieties in field experiments using different sowing dates: early and late plantings to expose the crop to high and low seasonal rainfall during the growing season, respectively. The experiments were constructed to simulate some of the many possible forms of drought stress scenarios that may occur in common bean farming in Ethiopia, as farmers plant at different dates within the rainy season, themselves. In this study, the drought-stress effects were principally of two types: terminal drought-stress (occurring at the end of the plant's growth cycle) and intermittent (occurring on and off but especially around the vegetative to early reproductive period of plant development).

The induction of drought stress in some experimental sites is through control of irrigation rather than by changing the specific sowing date. However, this can only be done in the dry season and in experiment stations with controlled water supplies. Unfortunately, many of these experimental conditions are not available in developing countries and even where they are the dry season may present conditions that are extremely different than the ones faced by farmers in terms of pests, diseases and temperature or photoperiod regimes. Therefore, early sowing as a means of exposing the crops to high seasonal rainfall and late sowing for exposing the crops to low seasonal rainfall seems valid option for evaluating drought tolerance in many bean growing regions. In eastern Africa and especially in the Ethiopian growing season, water deficits can occurs any time in the crops growth cycle, however are more common as terminal drought towards the end of the season or intermittent drought half-way through the growing season. The advantage of planting at different sowing dates in the rainy season is that the researcher emulates the conditions faced by farmers in a rainfed agriculture.

In farmers' fields it is not uncommon to have a false start to the rainy season with a short rainy period followed by a longer dry spell that exposes the early sown crops to drought-stress at vegetative and flowering stages of the crop growth. We observed such a season in Hawassa 2008 and used this to switch experimental consideration of the stress and nonstressed treatments. In that case, the early-sown crop was exposed to intermittent drought stress while an extended rainfall period over the latter part of the season provided the late-sown crop with adequate moisture for better yield formation within the same cropping season.

However, with normal seasonal rainfall patterns as were observed in 2009, late-sown crops often experience terminal drought-stress. The data on drought intensity 
index were severe for the drought-stress situations of Hawassa 2009 and Amaro 2009 cropping seasons. The drought conditions in those seasons as measured by drought severity indices were comparable with previous results reported for common beans grown under terminal drought in Ethiopia [4,20,21] and other drought studies reported in the tropics [30].

This indicated that designing experiments with different sowing dates can create a better opportunity for capturing consistent stress between experiments by exposing the crops to high and low seasonal rainfall during the growing season. An alternative is to use a rain-out shelter but this is very expensive for many experiment stations and limits the number of genotypes or plot sizes used in evaluation of the genotypes. Irrigation control is also not always reliable as a method of implementing droughtstress conditions especially when rains are intermittent as they are for most bean growing environments. The risk of overwatering the nonstress trial with irrigation plus rainfall is a real and present danger. Therefore, when managed drought stress either with a rain-out shelter covering the stress trial or with supplementary irrigation of nonstress trials is difficult to achieve, field testing with different sowing dates is a very valid technique. In such field testing, the number of sowing dates needs to be more than two to capture the possible drought patterns in the season. Reference [31] used five sowing dates to successfully explain phenological plasticity as mechanism of adaptation to rainfed environments in common bean grown in Colombia.

\subsection{Prioritization of Drought Tolerance Measurements}

Drought stress up-regulated or down-regulated trait expression in the varieties depending on which droughttolerance measurement was considered (Table 2). Drought stress accelerated flowering and maturity of the varieties while causing reduced grain yield. The reduction in grain yield in drought-stress was higher or lower based mainly on photosynthate translocation and partitioning traits. Therefore, drought-stress decreased number of pods per plant, seeds per pod and seed weight (relatively unfilled seed) affecting yield more severely in some genotypes than in others. Similar results were reported by various authors $[6-8,21,32,33]$.

The impact of drought stress on trait expression of the varieties varied. Some traits were more sensitive to drought stress than others. For instance, the effect of drought on photosynthate translocation and partitioning (PTP) traits was much more than that for yield component traits on the varieties studied (Table 2). This was attributed to differences between the varieties for adaptation to drought stress. In this study, the varieties that showed better adaptation to drought stress used different mechanisms for displaying better yield potential. Drought tolerant varieties like Hawassa Dume maintained better photosynthate translocation and partitioning than the drought sensitive varieties like Brown Speckled or Red Wolayta under drought stress. Although Red Wolayta was not efficient in partitioning photosynthetically assimilated carbon from the pod walls to the seed; it was similar to Hawasa Dume in producing better grain yield by better stem biomass reduction, harvest index and pods per plant under stress (Figures 3 and 4).

In selection for increased drought tolerance, varietal difference may result from differences in many mechanism of adaptation like differences in growth, phenology, photosynthate acquisition, translocation and partitioning, and hydraulic characteristics of the root system $[9,32$, $34,35]$. Tolerance is not a single trait but rather is the overall manifestation of the sum of the different mechanisms in the plant $[3,10,18]$. For example in some conditions earliness is a tolerance trait although in the sites and genotypes we evaluated early maturing varieties were not correlated with higher yields, but rather the opposite was true.

The multiple sub-trait nature of drought tolerance poses a challenge for plant breeders to pyramid the different mechanisms of drought tolerance. Furthermore, most of the individual drought-tolerance traits are also under complex polygenic control and to integrate these with grain yield and the other end-user preference characteristics like seed size and marketability is difficult. Our results, however, do indicate the relevance of continued high levels of photosynthate translocation and partitioning as an effective selection objective for improving drought adaptation in common bean. Reference [10] indicated common bean genotypes showing higher values of pod harvest index, pod partitioning index and a lower proportion of pod wall biomass were superior in their adaptation to drought stressed conditions. Better capacity to mobilize photoynthate to the developing grain improving yield potential under drought stress in common beans also reported by reference [36]. Stem reserve utilization for grain filling under drought stress is as an effective drought tolerance mechanism in crop plants [37]. Notably a breeding program has to prioritize and target those traits like overall yield which provide a genetic gain to farmers. In this regard, our result showing correlation of PTP and yield confirm that PTP can be a novel tolerance mechanism for targeting to improve drought adaptation breeding in common bean.

Increased or sustained harvestable yield is the main goal of common bean farming in Ethiopia and elsewhere. This goal is being challenged by drought stress linked with climate change. One of the strategies to minimize drought-induced yield reduction in common bean pro- 
duction is through use of productive varieties adapted to drought stress conditions [32,34]. Many of the common bean varieties released/recommended for production by farmers in Ethiopia have been indirectly tested for adaptation to farmers prevailing conditions through conventional approaches and participatory breeding [4]. Selection for higher grain yield and yield stability across locations and over years has been the main criteria.

Quantifying the level of drought tolerance in available varieties in the field trials like the ones carried out here would help in designing a breeding strategy that incurporates traits related to drought tolerance in varieties that are attractive to common bean farmers to be grown by their diverse environments. In this study, the variety Red Wolayta representing the local farmer variety in the southern region of Ethiopia showed good adaptation to stress conditions. This is in contrast to reference [21] who reported Red Wolayta as susceptible variety to drought. This variety has been cultivated in marginal drought prone farming system probably for more than a century and could provide valuable alleles for adaptation to stressful environments in breeding programs. Moreover, variety like Hawassa Dume performed well under both drought stress and nonstress conditions and also showed better yield stability. Both varieties are indeterminate in their growth habit and apparently showed phenotypic plasticity through regrowth after drought shock. Longer growth and indeterminacy could be an important adaptation under drought stress.

\section{ACKNOWLEDGEMENTS}

We are grateful for funding from the Tropical Legumes I project of the Generation Challenge Program with support from the Bill and Melinda Gates Foundation. The support provided by South Agricultural Research Institute (SARI), Ethiopia is also highly acknowledged.

\section{REFERENCES}

[1] Asfaw, A., Blair, M.W. and Almekinders, C. (2009) Genetic diversity and population structure of common bean (Phaseolus vulgaris L.) landraces from the East Africa highlands. Theoretical and Applied Genetics, 120, 1-12. http://dx.doi.org/10.1007/s00122-009-1154-7

[2] Broughton, W.J., Hernandez, G., Blair, M.W., Beebe, S.E., Gepts, P. and Vanderleyden, J. (2003) Beans (Phaseolus spp.) —model food legumes. Plant and Soil, 252, 55-128. http://dx.doi.org/10.1023/A:1024146710611

[3] Asfaw, A. (2011) Breeding for drought tolerance by integrative design: The case of common bean (Phaseolus vulgaris L.) in Ethiopia. Ph.D. Dissertation, Wageningen University, Wageningen.

[4] Asfaw, A., Almekinders, C.M.J., Blair, M.W. and Struik, P.C. (2012) Participatory approach in common bean breeding for drought tolerance for southern Ethiopia. Plant Breeding, 131, 125-134. http://dx.doi.org/10.1111/j.1439-0523.2011.01921.x

[5] Wortmann, C.S., Kirkby, R.A., Eledu, C.A. and Allen, D.J. (1998) Atlas of common bean (Phaseolus vulgaris L.) production in Africa. CIAT Pan-African Bean Research Alliance, CIAT Publication, Cali.

[6] Acosta-Gallegos, J.A., and Kohashi-Shibata, V. (1989) Effect of water stress on growth and yield of indeterminate dry bean (Phaesolus vulgaris) cultivars. Field Crops Research, 20, 81-90. http://dx.doi.org/10.1016/0378-4290(89)90054-3

[7] Acosta-Gallegos, J.A. and Adams, M.W. (1991) Plant traits and yield stability of dry bean (Phaseolus vulgaris) cultivars under drought stress. Journal of Agricultural Sciences, 117, 213-219. http://dx.doi.org/10.1017/S0021859600065308

[8] Muñoz-Perea, C.G., Terán, H., Allen, R.G., Wright, J.L., Westermann, D.T. and Singh, S.P. (2006) Selection for drought resistance in dry bean landraces and cultivars. Crop Science, 46, 2111-2120.

http://dx.doi.org/10.2135/cropsci2006.01.0029

[9] Asfaw, A., Blair, M.W. and Struik, P.C. (2012) Multienvironment quantitative trait loci analysis for photosynthate acquisition, accumulation and remobilization traits in common bean under drought stress. G3: Genes, Genomes and Genetics, 2, 579-595.

[10] Beebe, S.E., Rao, I.M., Blair, M.W. and Acosta-Gallegos, J.A. (2013) Phenotyping common beans for adaptation to drought. Frontier in Physiology, 4, 35. http://dx.doi.org/10.3389/fphys.2013.00035

[11] Masaya, P. and White, J.W. (1991) Adaptation to photoperiod and temperature. In: Schoonhoven, A. and Voysest, O., Eds., Common Beans: Research for Crop Improvement, C.A.B. Int., Wallingford and CIAT, Cali, 445-500.

[12] Nielsen, D.C. and Nelson, N. (1998) Black bean sensitivity to water stress at various growth stages. Crop Science, 38, 422-427.

http://dx.doi.org/10.2135/cropsci1998.0011183X0038000 $\underline{20025 x}$

[13] Ramĩrez-Vallejo, P. and Kelly, J.D. (1998) Traits related to drought resistance in common bean. Euphytica, 99, 127-138. http://dx.doi.org/10.1023/A:1018353200015

[14] Asfaw, A. and Blair, M.W. (2012) Quantitative trait loci for rooting pattern traits of common beans grown under drought stress versus nonstress. Molecular Breeding, 30, 681-695. http://dx.doi.org/10.1007/s11032-011-9654-y

[15] Serraj, R. and Sinclair, T.R. (1998) N2 fixation response to drought in common bean (Phaseolus vulgaris L.). Annals of Botany, 82, 229-234.

http://dx.doi.org/10.1006/anbo.1998.0670

[16] Guida dos Santos, M., Vasconcelos, R., Ferraz, R. and Pimentel, C. (2004) Gas exchange and yield response to foliar phosphorus application in Phaseolus vulgaris L. under drought. Brazilian Journal of Plant Physiology, 16, 171-179. http://dx.doi.org/10.1590/S1677-04202004000300007

[17] Thung, M. and Rao, I.M. (1999) Integrated management of abiotic stresses. In: Singh, S.P., Ed., Common Bean Improvement in the Twenty-First Century, Kluwer Aca- 
demic Publishers, Dordrecht, 331-370. http://dx.doi.org/10.1007/978-94-015-9211-6_13

[18] Rao, I.M. (2001) Role of physiology in improving crop adaptation to abiotic stresses in the tropics: The case of common bean and tropical forages. In: Pessarakli, M., Ed., Handbook of Plant and Crop Physiology, Marcel Dekker, Inc., New York, 583-613.

[19] Jones, P.G. and Thornton, P.K. (2003) The potential impacts of climate change on maize production in Africa and Latin America in 2055. Global Environmental Change, 13, 51-59. http://dx.doi.org/10.1016/S0959-3780(02)00090-0

[20] Abebe, A., Brick, M.A. and Kirkby, R.A. (1998) Comparison of selection indices to identify productive dry bean lines under diverse environmental conditions. Field Crops Research, 58, 15-23. http://dx.doi.org/10.1016/S0378-4290(98)00082-3

[21] Rezene, Y., Gebeyehu, S. and Habitamu, Z. (2013) Morpho-physiological response to post-flowering drought stress in small seeded common bean (Phaseolus vulgaris L.) genotypes. Journal of Plant Studies, 2, 36-41.

[22] Payne, R.W., Harding, S.A., Murray, D.A., Soutar, D.M., Bird, D.B., et al. (2009) The guide to GenStat Release 12, statistics. VSN International, Hemel Hempstead, Hertfordshire, UK

[23] Gilmour, A.R., Cullis, B.R. and Verbyla, A.P. (1997) Accounting for natural and extraneous variation in the analysis of field experiments. Journal of Agricultural Biology and Environmental Statistics, 2, 269-293. http://dx.doi.org/10.2307/1400446

[24] Hallauer, A.R., Carena, M.J. and Miranda Filho, J.B. (2010) Quantitative genetics in maize breeding. Iowa State University Press, Ames.

[25] Fischer, R.A. and Maurer, R. (1978) Drought resistance in spring wheat cultivars. 1. Grain yield response. Australian Journal of Agricultural Research, 29, 897-912. http://dx.doi.org/10.1071/AR9780897

[26] Fernández, G.C.J. (1992) Effective selection criteria for assessing plant stress tolerance. Proceedings of the International Symposium on "Adaptation of Vegetables and other Food Crops in Temperature and Water Stress", Taiwan, 13-16 August 1992, 257-270.

[27] Rosielle, A.A. and Hamblin, J. (1981) Theoretical aspects of selection for yield in stress and nonstress environments. Crop Science, 21, 943-946. http://dx.doi.org/10.2135/cropsci1981.0011183X0021000 $\underline{60033 x}$

[28] Lin, C.S. and Binns, M.R. (1988) A superiority measure of cultivar performance for cultivar x location data. $\mathrm{Ca}$ - nadian Journal of Plant Science, 68, 193-198. http://dx.doi.org/10.4141/cjps88-018

[29] Yan, W. (2001) GGE biplot: A windows application for graphical analysis of multi-environment trial data and other types of two-way data. Agronomy, 93, 1111-1118.

[30] Terán, H. and Singh, S.P. (2002) Comparison of sources and lines selected for drought resistance in common bean. Crop Science, 42, 64-70. http://dx.doi.org/10.2135/cropsci2002.0064

[31] Acosta-Gallego, J.A. and White, W. (1995) Phenological plasticity as an adaptation by common bean rainfed environment. Crop Science, 35, 199-204.

http://dx.doi.org/10.2135/cropsci1995.0011183X0035000 $10037 \mathrm{x}$

[32] Nleya, T.M., Slinkard, A.E. and Vandenberg, A. (2001) Differential performance of pinto bean under varying levels of soil moisture. Canadian Journal of Plant Science, 81, 233-239. http://dx.doi.org/10.4141/P99-180

[33] Blair, M.W., Galeano, C.H., Tovar, E., Muñoz-Torres, M.C., Velasco, A., Beebe, S.E. and Rao, I.M. (2012) Development of a Mesoamerican intra-genepool genetic map for QTL detection in a drought tolerant x susceptible common bean (Phaseolus vulgaris L.) cross. Molecular Breeding, 29, 71-88. http://dx.doi.org/10.1007/s11032-010-9527-9

[34] Rosales-Serna, R., Koshashi, J., Acosta-Gallegos, J.A., Trejo-Lõpeza, C., Ortiz-Cereceres, J. and Kelly, J.D. (2004) Biomass distribution, maturity acceleration and yield in drought-stressed common bean cultivars. Field Crops Research, 85, 203-211. http://dx.doi.org/10.1016/S0378-4290(03)00161-8

[35] Lizana, C., Wentworth, M., Martinez, J.P., Villegas, D., Meneses, R., Murchie, E.H., Pastenes, C., Lercari, B., Vernieri, P., Horton, P. and Pinto, M. (2006) Differential adaptation of two varieties of common bean to abiotic stress. Journal of Experimental Botany, 54, 685-697. http://dx.doi.org/10.1093/jxb/erj062

[36] Klaedtke, S.M., Cajiao, C., Grajales, M., Polania, J., Borrero, G. and Guerrero, A. (2012) Photosynthate remobilization capacity from drought-adapted common bean (Phaseolus vulgaris L.) lines can improve yield potential of inter-specific populations with in the secondary genepool. Journal of Plant Breeding and Crop Science, 4, 49-61.

[37] Blum, A. (2005) Drought resistance, water use efficiency, and yield potential-Are they compatible, dissonant, or mutually exclusive? Australian Journal of Agricultural Research, 56, 1159-1168. http://dx.doi.org/10.1071/AR05069 